\title{
Dukungan Spiritual Dengan Tingkat Stres Pada Narapidana di Lembaga Pemasyarakatan Kelas II A Bulukumba Tahun 2020
}

\author{
${ }^{1}$ Nurlina \\ ${ }^{2}$ Haerati
}

${ }^{1}$ Prodi S1 Keperawatan,Stikes Panrita Husada Bulukumba, Indonesia

${ }^{2}$ Prodi S1 Keperawatan, Stikes Panrita Husada Bulukumba, Indonesia

\section{Alamat Koresponden :}

Nurlina

BTN Rindra 5 Taccorong

Kabupaten Bulukumba

Hp. 085398815544

Email: nurlinapanrita@gmail.com 


\begin{abstract}
ABSTRAK
Stres adalah suatu reaksi fisik dan psikis terhadap setiap tuntutan yang menyebabkan ketegangan dan mengganggu stabilitas kehidupan sehari-hari. Sebagian besar seseorang mengalami stres adalah narapidana. Jumlah warga binaan di Provinsi Sulawesi Selatan pada tahun 2018 adalah 10.286 orang diantaranya 336 orang warga binaan di Lapas Bulukumba. Jika stres ini berlangsung lama, dapat mengakibatkan timbulnya dampak bagi tubuh seseorang. Oleh karena itu, upaya pencegahan untuk menangani stres, maka diberikan dukungan secara spiritual. Tujuanya untuk mengetahui hubungan antara dukungan spiritual dengan tingkat stres pada narapidana dengan kasus narkoba di Lembaga Pemasyarakatan Kelas II A Bulukumba tahun 2020. Metode penelitian ini menggunakan penelitian analitik, dengan desain Cross sectional. Populasi pada penelitian ini adalah narapidana dengan kasus narkoba. Sampel pada penelitian ini berjumlah 47 responden dengan tekhnik pengambilan sampel menggunakan metode Consecutive sampling. Pengambilan data dilakukan dengan menggunakan lembar kuesioner pada dukungan spiritual dan DASS 42 (Depression Anxiety and Stress Scale 42). Analisa data yang digunakan dengan menggunakan uji Chi-Square. Pada penelitian ini diperoleh hasil bahwa dukungan spiritual yang mendukung dengan kategori kurang stres lebih banyak 21 responden $(87,5 \%)$ dibandingkan dengan yang stres 3 responden (12,5\%). Sedangkan dukungan spiritual yang tidak mendukung dengan kategori stres sebanyak 23 responden (100\%). Berdasarkan analisis yang telah dilakukan dengan menggunakan uji Chi-Square, maka diperoleh nilai $p$-value $=0,000(\mathrm{p}<0,05)$. Terdapat hubungan dukungan spiritual dengan tingkat stres pada narapidana di Lembaga Pemasyarakatan Kelas II A Bulukumba. Disarankan kepada petugas Lapas dan tenaga kesehatan di Lapas untuk selalu memperhatikan kondisi kesehatan mental narapidana. Diharapkan juga pada responden untuk meningkatkan spiritualnya dengan cara memperbanyak mengikuti kegiatan keagamaan.
\end{abstract}

\title{
Kata Kunci: Dukungan Spiritual, Tingkat Stres, Narapidana
}

\begin{abstract}
Stress is a physical and psychological reaction to any demands that cause tension and disturb the stability of everyday life. Most people experiencing stress are prisoners. The number of fostered residents in South Sulawesi Province in 2018 was 10,286 including 336 fostered residents in Lapas Bulukumba. If this stress lasts a long time, it can have an impact on one's body. Therefore, prevention efforts to deal with stress, are given spiritual support. This study aims to determine the relationship between spiritual support and stress levels in prisoners with drug cases in Class II A Penitentiary in Bulukumba in 2019. The method of research is using research analytic, with design cross-sectional. The population in this study is prisoners with drug cases. The samples in the study have amounted to 47 respondents with the technique of taking samples using methods of Consecutive sampling. Retrieval of data is done by using a sheet questionnaire on the support of the spiritual and the DASS 42 ( Depression Anxiety and Stress Scale 42 ). Analysis of the data used by using the Chi-Square test. In research, it obtained results that support spiritual support to the category of less stress over lots of 21 respondents (87.5\%) compared with the stress of three respondents (12.5\%). While the support of spirituality does not support the category of stress as much as 23 respondents (100\%). Based on the analysis that has been done by using test Chi-Square, the obtained value p-value $=0.000(p<0.05)$. There is a relationship of support spiritual with the level of stress on inmates at the Institute of Corrections Class II A Bulukumba. It is recommended to prison staff and health workers in prison to always pay attention to the mental health conditions of inmates. It is expected also on the respondents to increase the spiritual by way of multiplying follow the activities of the religious.
\end{abstract}

Keyword : Support Spiritual, Level of Stress, Inmates 


\section{PENDAHULUAN}

Stres adalah kondisi yag tidak menyenangkan dimana manusia melihat adanya tuntutan dalam suatu situasi sebagai beban atau di luar batasan kemampuan mereka untuk memenuhi tuntutan tersebut. Di samping itu, keadaan stres yang tidak mampu untuk di atasi atau mengalami stres berat, sehingga akan mengancam keselamatan atau integritas seseorang, dan bahkan beresiko untuk membahayakan diri sendiri maupun orang lain bahkan dapat terjadi percobaan bunuh diri (Nasir and Muhith, 2011).

Berdasarkan data World Health Organization pada tahun 2017 menyebutkan bahwa sekitar 450 juta orang di dunia mengalami stres. Di Amerika sekitar $75 \%$ orang dewasa mengalami stres berat dan jumlahnya cenderung meningkat dalam satu tahun terakhir. Sementara itu di Indonesia tercatat sekitar $10 \%$ dari total penduduk Indonesia mengalami stres, dengan tingkat stres akut mencapai 1-3\% dan stres berat mencapai 7-10\% (WHO, 2017). Data menurut Riskesdas menyebutkan bahwa prevalensi stres di Sulawesi Selatan mengalami kenaikan dari tahun 2013 sebesar 7,5\% naik menjadi $13 \%$ di tahun 2018. Data tersebut menunjukkan bahwa stres bersifat universally, dimana semua orang dapat merasakannya tetapi cara pengungkapannya yang berbeda. Stres di timbulkan karena dipengaruhi oleh faktor lingkungan seperti kondisi dan situasi tempat tinggak serta pengalaman masa lalu individu (Riskesdas, 2018).

Sebagian besar seseorang yang mengalami stres adalah narapidana. Berdasarkan data Direktorat Jendral Pemasyarakatan mencatat bahwa jumlah warga binaan di Provinsi Sulawesi Selatan pada tahun 2018 adalah 10.286 orang, dengan kapasitas sebanyak 5.765 orang. Jika dilihat dari jumlah warga binaan di Sulawesi Selatan ternyata melebihi kapasitas (Direktorat Jendral Pemasyarakatan, 2018). Berdasarkan hasil studi pendahuluan yang dilakukan di Lapas Bulukumba pada bulan April 2020 didapatkan jumlah warga binaan sebanyak 336 orang dengan kapasitas 300 orang dan hal ini juga mengalami kelebihan kapasitas yang artinya semakin banyak warga binaan yang akan mengalami gangguan psikologis salah satunya stres.

Hal ini di buktikan dengan hasil wawancara langsung kepada 5 narapidana di Lapas Kelas II A Bulukumba pada bulan April 2020 menunjukkan bahwa faktor pemicu stres narapidana yaitu tidak mendapatkan kebebasan fisik, jauh dari keluarga, memikirkan istri dan anaknya, memikirkan lama masa hukuman, memikirkan persepsi orang tentang dirinya, serta memikirkan bagaimana caranya bersosialisasi kembali setelah keluar dari 
penjara. Dari ke-5 narapidana yang di wawancarai, 3 narapidana yang mengatakan bahwa sering mendapatkan dukungan, motivasi dan arahan dari ustadz maupun pegawai lapas, serta selalu mengikuti kegiatan-kegiatan yang dilaksanakan oleh lembaga, sehingga selama berada di penjara mereka menjadi lebih tenang, dan menjadi pribadi yang lebih baik.

Berdasarkan penelitian yang dilakukan oleh Gunawan and Yahya tahun 2016 menunjukkan bahwa adanya pengaruh kaligrafi terhadap tingkat stres narapidana. Sejalan dengan penelitian yang dilakukan oleh Faizin tahun 2016 dengan hasil menunjukkan adanya hubungan positif antara intensitas dzikir dan optimisme kesembuhan pada pecandu narkoba.

Tujuan penelitian ini adalah untuk menganalisis hubungan dukungan spiritual dengan tingkat stres pada narapidana dengan kasus narkoba di Lembaga Pemasyarakatan Kelas II A Bulukumba tahun 2020.

\section{METODE PENELITIAN}

Jenis penelitian ini adalah jenis penelitian kuantitatif. Desain penelitian ini menggunakan penelitian analitik dengan pendekatan cross sectional, dimana variabel independen dan variabel dependen diidentifikasi pada satu satuan waktu (Dharma, 2011).
Populasi merupakan seluruh subjek atau objek dengan karakteristik tertentu yang akan diteliti, bukan hanya objek atau subjek uang dipelajari saja tetapi seluruh karakteristik atau sifat yang dimiliki subjek atau objek tertentu (Hidayat, 2018). Populasi dalam penelitian ini adalah narapidana dengan kasus narkoba sebanyak 160 orang.

Teknik sampel pada penelitian ini menggunakan metode Consecutive sampling yaitu, suatu metode pemilihan sampel yang dilakukan dengan memilih semua individu yang ditemui dan memenuhi kriteria pemilihan, sampai jumlah sampel yang diinginkan terpenuhi (Dharma, 2011). Besar sampel dalam penelitian ini adalah 47 orang dengan menggunakan rumus besar sampel menurut (Dahlan, 2011).

Instrumen yang digunakan pada penelitian ini adalah instrumen dalam bentuk kuesioner yang telah teruji valid dan reliable. Instrumen yang digunakan untuk dukungan spiritual adalah kuesioner yang diadopsi milik (Nilamastuti, 2016) yang terdiri dari 26 pernyataan menggunakan skala likers. Sedangkan instrumen yang digunakan untuk tingkat stres adalah kuesioner DASS 42 yang diadopsi dan dikembangkan dari Lovibond, S.H \& Lovibond, P.F, yang dikutip dalam penelitian (Nilamastuti, 2016) yang terdiri dari 14 pernyataan. 
Data dianalisis berdasarkan skala ukur dan tujuan penelitian dengan menggunakan program SPSS. Data dianalisis secara : (1). Analisis Univariat, Analisis digunakan untuk menjabarkan secara deskriptif mengenai distribusi frekuensi dan proporsi setiap variabel penelitian. (2). Analisis Bivariat, Analisis ini digunakan untuk menguji hipotesis dengan menentukan hubungan antara variabel independen dan variabel dependen dengan menggunakan uji chi-square bila memenuhi syarat, dan fisher's exact sebagai alternative. Interval kepercayaan yang diambil adalah $95 \%$ dan batas kemaknaan yang diterima apabila $p<0,05$.

\section{HASIL}

Berdasarkan Tabel 1 menunjukkan sebagian besar usia responden berada pada kategori dewasa sebanyak 32 responden $(68,1 \%)$, sebagian besar responden berjenis kelamin laki-laki sebanyak 44 responden (93,6\%), sebagian besar responden telah menikah sebanyak 30 responden $(63,8 \%)$, sebagian besar pendidikan responden berada pada tingkat SMA sebanyak 26 responden $(55,3 \%)$, dan masa hukuman responden rata-rata 5 tahun setengah.

Berdasarkan Tabel 2 dan 3 menunjukkan distribusi jumlah responden berdasarkan dukungan spiritual dan tingkat stres pada narapidana.

Untuk dukungan spiritual menunjukkan bahwa responden yang dukungan spiritualnya mendukung lebih banyak 24 responden $(51,1 \%)$, dibandingkan dengan tidak mendukung 23 responden $(48,9 \%)$. Untuk tingkat stres menunjukkan bahwa responden yang mengalami stres lebih banyak 26 responden $(55,3 \%)$, dibandingkan dengan yang kurang stres 21 responden (44,7\%).

Berdasarkan Tabel 4 menunjukkan hubungan dukungan spiritual dengan tingkat stres pada narapidana, dimana jika dukungan spiritualnya mendukung, maka tingkat stresnya lebih kecil 3 respoden $(12,5 \%)$ dibandingkan dengan dukungan spiritual tidak mendukung 23 responden (100\%). Hal ini menunjukkan bahwa ada perbedaan proporsi dukungan spiritual terhadap tingkat stres. Hasil uji Chi Square, diperoleh nilai $p=0,000(p<0,05)$, maka disimpulkan bahwa ada hubungan dukungan spiritual dengan tingkat stress pada narapidana.

\section{PEMBAHASAN}

Pada penelitian ini terlihat bahwa terdapat hubungan yang signifikan antara dukungan spiritual dengan tingkat stres pada narapidana dengan kasus narkoba di Lembaga Pemasyarakatan Kelas II A Bulukumba.

Dari hasil uji Chi Square, diperoleh nilai $p=0,000(p<0,05)$, maka disimpulkan bahwa ada hubungan dukungan spiritual dengan tingkat stress pada narapidana. Hal ini sesuai dengan 
teori Ah et al., tahun 2017 yang menyatakan bahwa keyakinan spiritual menjadi sumber dukungan bagi seseorang untuk menghadapi situasi stress. Sejalan dengan penelitian Gunawan and Yahya tahun 2016 dengan hasil penelitian terdapat pengaruh kaligrafi terhadap tingkat stres narapidana dengan nilai $p=0,013$. Didukung dengan hasil penelitian yang dilakukan oleh Rachmawati tahun 2019 didapatkan hasil terdapat hubungan tingkat spiritual dengan tingkat stres pada narapidana dengan nilai $p=0,001$.

Peneliti berpendapat bahwa semakin baik dukungan spiritual maka tingkat stres yang dimiliki oleh narapidana semakin berkurang. Spiritual adalah keyakinan dalam hubungannya dengan Yang Maha Kuasa dan Maha Pencipta. Sedangkan stres adalah reaksi atau respon tubuh terhadap stressor psikososial atau terhadap tekanan mental atau beban kehidupan. Sehingga dukungan spiritual sangat penting digunakan oleh individu untuk memecahkan masalah, dan terbebas dari stres yang berkepanjangan.

Peneliti berasumsi bahwa responden yang dukungan spiritualnya mendukung dan tidak mengalami stres karena responden dapat mengatasi stresnya dengan cara melakukan hal-hal yang positif, seperti mengikuti kegiatan keagamaan. Sedangkan responden yang dukungan spiritualnya mendukung dan mengalami stres disebabkan karena pola koping yang tidak kuat, dimana pola koping dipengaruhi oleh pola pikir dan perilakunya. Sedangkan responden yang dukungan spiritualnya tidak mendukung dan mengalami stres karena dukungan yang didapatkan masih kurang, dan pemahaman setiap responden ini berbeda. Sehingga tidak terpenuhinya karakteristik spiritual responden yaitu hubungan dengan Tuhan, alam, diri sendiri dan orang lain. Selain itu faktor lain yang dapat mempengaruhi stres yaitu dari karakteristik responden yang telah menikah dan lama masa tahanan.

\section{KESIMPULAN DAN SARAN}

Berdasarkan hasil penelitian diatas maka disimpulkan bahwa terdapat hubungan proporsi antara dukungan spiritual dengan tingkat stres pada narapidana di Lembaga Pemasyarakatan Bulukumba. Hasil penelitian ini hendaknya dijadikan pedoman petugas lapas untuk selalu memperhatikan kondisi kesehatan mental narapidana. Serta diharapkan responden mampu meningkatkan spiritualnya dengan cara memperbanyak mengikuti kegiatan keagamaan sehingga mampu mengatasi stres yang dimiliki.

\section{DAFTAR PUSTAKA}

Ah, Y. et al. (2017) Kebutuhan Spiritual: Konsep dan Aplikasi dalam Asuhan Keperawatan. Jakarta: Mitra Wacana Media. 
Dahlan, M.S. (2011) Langkah-langkah Membuat Proposal Penelitian Bidang Kedokteran dan Kesehatan. 2nd edn. Jakarta: Sagung Seto.

Dharma, K.K. (2011) Metodologi Penelitian Keperawatan (Panduan Melaksanakan dan Menerapkan Hasil Penelitian). Edisi Revi. Jakarta: TIM.

Direktorat Jendral Pemasyarakatan (2018) Sistem Database Pemasyarakatan, Indonesia. Available at: http://smslap.ditjenpas.go.id/public/g $\mathrm{rl} /$ current/monthly/year/2018/month/ 12 (Accessed: 31 December 2018).

Faizin, M.C. (2016) Hubungan Antara Intensitas Dzikir Dengan Optimisme Kesembuhan Pada Pecandu Narkoba Di Pondok Rehabilitasi, Jurnal Ilmiah Psikologi, (Skripsi).

Gunawan, I. \& Yahya (2016) Pelatihan Kaligrafi Terhadap Tingkat Stress Narapidana, Jurnal Psikoislamika, (Skripsi).

Hidayat, A.A.A. (2018) Metodologi Penelitian Keperawatan dan Kesehatan. Jakarta: Salemba Medika.

Nasir, A. \& Muhith, A. (2011) DasarDasar keperawatan Jiwa: Pengantar
Dan Teori. Jakarta: Salemba Medika. Nilamastuti, M.T. (2016) Hubungan Tingkat Spiritual dengan Tingkat Stres Pada Narapidana di Lembaga Permasyarakatan Kelas IIA Kabupaten Jember (Skripsi).

Rachmawati, H. (2019) Hubungan Tingkat Spiritual Dengan Tingkat Stres Pada Narapidana Di Lembaga Pemasyarakatan Kelas II B Kota Mojokerto, Jurnal Penelitian STIKES Bina Sehat PPNI Mojokerto (Skripsi).

Riskesdas (2018) Hasil Utama Riskesdas 2018: Kementrian Kesehatan Badan Penelitian dan Pengembangan Kesehatan. Available at: http://www.depkes.go.id/resources/d ownload/infoterkini/materi_rakorpop_2018/Hasil Riskesdas 2018.pdf.

WHO (2017) Depression and Other Common Mental Disorders : Global Health Estimates. Available at: https://apps.who.int/iris/bitstream/ha ndle/10665/254610/WHO-MSDMER-2017.2eng.pdf;jsessionid=887A853057D51 507C5E919E0DEA2E83F?sequence $=1$. 
Tabel 1. Distribusi Frekuensi Berdasarkan Karakteristik Responden

\begin{tabular}{lcc}
\hline \multicolumn{1}{c}{ Karakteristik Responden } & Frekuensi (f) & Persentasi (\%) \\
\hline Usia & 13 & 27.7 \\
Remaja (12-25) & 32 & 68.1 \\
Dewasa (26-45) & 2 & 4.3 \\
Lansia (>45) & & \\
Jenis Kelamin & 44 & 93.6 \\
$\quad$ Laki-laki & 3 & 6.4 \\
$\quad$ Perempuan & & \\
Status Pernikahan & 30 & 63.8 \\
Menikah & 17 & 36.2 \\
Belum Menikah & & \\
Pendidikan & 4 & 8.5 \\
$\quad$ SD & 15 & 31.9 \\
SMP & 26 & 55.3 \\
SMA & 2 & 4.3 \\
Diploma & 5.94 & - \\
Masa Hukuman & 5.0 & - \\
Mean (Nilai Rata-rata) & 10.0 & - \\
Minimum (Nilai Rata-rata) & $\mathbf{4 7}$ & $\mathbf{1 0 0 . 0}$ \\
Maximum (Nilai Rata-rata) & Jumlah &
\end{tabular}

Tabel 2. Jumlah Responden Berdasarkan Dukungan Spiritual

\begin{tabular}{ccc}
\hline Dukungan Spiritual & Frekuensi (f) & Persentasi (\%) \\
\hline Mendukung & 24 & 51.1 \\
Tidak Mendukung & 23 & 48.9 \\
\hline Jumlah & $\mathbf{4 7}$ & $\mathbf{1 0 0 . 0}$ \\
\hline
\end{tabular}

Tabel 3. Jumlah Responden Berdasarkan Tingkat Stres

\begin{tabular}{ccc}
\hline Tingkat Stres & Frekuensi (f) & Persentasi (\%) \\
\hline Stres & 26 & 55.3 \\
Kurang Stres & 21 & 44.7 \\
\hline Jumlah & $\mathbf{4 7}$ & $\mathbf{1 0 0 . 0}$ \\
\hline
\end{tabular}

Tabel 4. Hubungan Dukungan Spiritual Dengan Tingkat Stres Pada Narapidana

\begin{tabular}{|c|c|c|c|c|c|c|c|}
\hline \multirow{3}{*}{ Dukungan Spiritual } & \multicolumn{4}{|c|}{ Tingkat Stres } & \multirow{2}{*}{\multicolumn{2}{|c|}{ Jumlah }} & \multirow[t]{3}{*}{ Nilai $p$} \\
\hline & \multicolumn{2}{|c|}{ Stres } & \multicolumn{2}{|c|}{ Kurang Stres } & & & \\
\hline & $\mathbf{f}$ & $\%$ & $\mathbf{f}$ & $\%$ & $\mathbf{N}$ & $\%$ & \\
\hline Mendukung & 3 & 12.5 & 21 & 87.5 & 24 & 100.0 & 0.000 \\
\hline Tidak Mendukung & 23 & 100.0 & 0 & 0.0 & 23 & 100.0 & \\
\hline Jumlah & 26 & 55.3 & 21 & 44.7 & 47 & 100.0 & \\
\hline
\end{tabular}

